$\sqrt{3}$

J. bio-sci. 16: 109-114, 2008

ISSN 1023-8654

http://www.banglajol.info/index.php/JBS/index

\title{
STUDY ON THE DEVELOPMENTAL STAGES OF SPIDER MITE (TETRANYCHUS URTICAE KOCH) INFESTING COUNTRY BEAN
}

\author{
Najmoon Naher, Md Wahedul Islam, ${ }^{1^{*}}$ M Khalequzzaman and Mohd Mainul Haque* \\ Institute of Biological Sciences, University of Rajshahi, Rajshahi, Bangladesh \\ "Department of Zoology, University of Rajshahi, Rajshahi, Bangladesh
}

\begin{abstract}
The duration of developmental stages of Tetranychus urticae Koch was studied in different months of a year at room temperature. In addition fecundity of this mite was also observed in winter, autumn and summer seasons. T. urticae eggs hatched to larvae in the shortest duration of $1.07 \pm 0.26$ days and the longest duration of $11.67 \pm 2.33$ days in April and January, respectively. The larval period of $T$. urticae took the shortest time of $0.55 \pm 0.50$ days in May and $2.93 \pm 1.07$ days in December. The protonymph transformed to deutonymph in $0.89 \pm 0.32$ day in May and $3.71 \pm 1.94$ in December and January. The deutonymph required the shortest duration of $0.92 \pm 0.41$ days in August and the longest of $10.26 \pm$ 1.48 days in January. The temperature played significant $(P<0.001)$ role on the duration of developmental stages of $T$. urticae. The high temperature accelerated the developmental rate and reduced the duration of developmental periods. Its life cycle completed within $4.22 \pm 0.46$ days at 28.53 $\pm 3.17^{\circ} \mathrm{C}$ but $28.33 \pm 2.36$ days at $13.78 \pm 2.36^{\circ} \mathrm{C}$. A female $T$. urticae deposited $82.46 \pm 4.11$ eggs in autumn, $62.96 \pm 12.09$ eggs in summer and $58.21 \pm 13.65$ eggs in winter.
\end{abstract}

Key words: Developmental stages, Tetranychus urticae, temperature, fecundity

\section{Introduction}

Tetranychus urticae Koch is one of the most serious pests of various crops and vegetables in agriecosystem. It is also a serious pest of ornamental plants and fruit trees in both greenhouse and field. T. urticae was first reported from the USA by Tuttle and Baker (1968). It has wide host range including vegetables, ornamentals, herbaceous and woody landscape plants, and has been recorded to feed more than 180 plant species (Johnson and Lyon 1991).

The life cycle of $T$. urticae is typical of warm weather spider mites. It completes development from egg to adult within $7-8$ days at $27.5-32.5^{\circ} \mathrm{C}$ and all the life stages present throughout the year, depending on the environmental conditions (Helle and Sabelis 1985). Development proceed more slowly when temperature is minimum, requiring upto four weeks for total life span. Host plants, plant nutrition, leaf age, and moisture stress also influence development of $T$. urticae. Many generations passes in each year, depending on the species of spider mites. Some species of spider mites, the Southern red mite and the European red mite occurring on conifers and broad-leaved evergreen plants are called cool weather pests. They feed heavily and reproduce quickly in spring and fall (Helle and Sabelis 1985).

T. urticae abundantly occurs on bean plants in the City Corporation area of Rajshahi. This mite causes serious damage to bean plants (Naher 2005). Its control is very much essential to get maximum and quality yield of bean. For successful management of any pest, a through knowledge about biology of the pest is necessary. Keeping this in mind an experiment was designed to study the biology and fecundity of $T$. urticae infesting country bean plants, Lablab purpureusi $\mathrm{L}$.

*Corresponding address: mwislam2001@yahoo.com 


\section{Materials and Methods}

Developmental stages: The duration of developmental stages was studied on excised leaf disc in the Integrated Pest Management (IPM) laboratory, Institute of Biological Sciences, Rajshahi University from March 2002 to January 2003. Leaf discs were made with fresh country bean (L. purpureus) leaf without mite infestation. Each leaf disc was circular in appearance with $2 \mathrm{~cm}$ diameter. Thirty leaf discs were prepared.

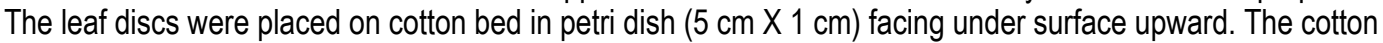
bed was kept wet by soaking with water twice daily so that the discs remained fresh.

Two adult female $T$. urticae (those can be easily separated from male with their oval abdomen and absence of aedeagus) were transferred to each leaf disc for laying eggs. The adult female mites were collected from the laboratory maintained in the Institute Biological Sciences by rearing $T$. urticae on potted bean plants for more than one year.

The discs containing adult females were checked after two hours of mite transfer. The mites were removed if at least one egg was found. In this way 30 eggs were collected on leaf discs. Keeping only one egg on each disc the others were destroyed by pin. There was always a gap between bottom dish and lid. The discs were checked after every $24 \mathrm{~h}$ and the stages of mite development were noted till the appearance of their adulthood. The leaf discs were changed after 3 to 4 days to ensure their freshness. The immatures were transferred to new disc very carefully with the help of camel hair brush. The room temperature and relative humidity was recorded twice daily.

The duration of hatching, larval, protonymphal and deutonymphal period was recorded for 11 generations with the mean temperature and relative humidity of $25.82^{\circ} \mathrm{C}, 67.48 \%$ (March); $27.466^{\circ} \mathrm{C}, 76.75 \%$ (April); $28.53^{\circ} \mathrm{C}, 82.90 \%$ (May); $29.60^{\circ} \mathrm{C}, 85.49 \%$ (June); $30.06^{\circ} \mathrm{C}, 87.41 \%$ (July); $29.41^{\circ} \mathrm{C}, 85.82 \%$ (August); $29.36^{\circ} \mathrm{C}, 85.92 \%$ (September); $27.07^{\circ} \mathrm{C}, 82.31 \%$ (October); $23.32^{\circ} \mathrm{C}, 80.35 \%$ (November); $18.59^{\circ} \mathrm{C}, 81.83 \%$ (December) and $13.78^{\circ} \mathrm{C}, 80.21 \%$ (January). But every times the eggs were collected from fresh adult female maintained in the laboratory culture. The developmental successes of various developmental stages in different generations were calculated.

Fecundity of T. urticae: Deutonymphs of $T$. urticae were collected from the potted bean plants of laboratory culture. Five to six deutonymph were transferred on each leaf disc. The disc containing deutonymphs were observed twice daily at 6 AM and 6 PM. The time of adulthood of the deutonymphs was recorded. All the mites were removed keeping one male and one female on each disc. The male was also removed after laying the first egg by the female. In this way more than 30 discs with ovipositing females were maintained for this experiment. The discs were checked after every 24 hours interval with the aid of a stereo binoculor microscope. The leaf discs were also changed after every three days in the same way as described earlier. All the discs were checked and the number of eggs laid was counted till the death of the adult. The room temperature and relative humidity was recorded twice daily. The experiment was conducted in three seasons viz., summer, autumn and winter at temperature and relative humidity $30.46^{\circ} \mathrm{C}, 82.78 \% ; 25.23^{\circ} \mathrm{C}$, $83.91 \%$; and $13.88^{\circ} \mathrm{C}^{\circ} \mathrm{C}, 80.35 \%$ respectively.

\section{Results and Discussion}

Developmental stages: T. urticae passes four developmental stages with resting or quiescent stages at the end of larval and nymphal development. The duration of various developmental stages of $T$. urticae in different generations maintained in different months (Table 1).

T. urticae eggs hatched to six legged larvae in the shortest duration of $1.07 \pm 0.26$ days in the month of April. It took the longest duration of $11.67 \pm 2.33$ days in the month of January (Table 1). The eggs of $T$. urticae hatched rapidly in April when the temperature was $27.46 \pm 3.17^{\circ} \mathrm{C}$ (Table 3). But the eggs hatched slowly in January when the temperature was $13.78 \pm 3.21^{\circ} \mathrm{C}$ (Table 3). T. urticae larvae transformed to eight legged protonymph after a while. Before transforming to protonymph it passed a short inactive period which called 
crysalis. It left an exuvie during this transformation. The larval period was the shortest in duration compared to all other developmental stages. It took $0.55 \pm 0.50$ (Table 1) days in the month of May. The protonymphal duration of $T$. urticae was also the shortest in the month of May. It took $0.89 \pm 0.32$ days from protonymph to deutonymph. The highest duration was $3.71 \pm 1.94$ days in December and January. The deutonymph is the last immature stage of $T$. urticae life cycle. It required the shortest duration of $0.92 \pm 0.41$ days in August and the longest $10.26 \pm 1.48$ days in January. During May the average temperature was $28.53 \pm 3.17^{\circ} \mathrm{C}$ (Table 3) and was very favourable for mite development. The lowest average temperature $13.78 \pm 3.21^{\circ} \mathrm{C}$ was prevailed in the month of January retarded the developmental rate and lengthened the transformation of deutonymph to adult.

The effect of temperature and relative humidity on the duration of developmental stages are studied and the calculated ' $r$ ' values are presented in Table 2. Duration of developmental stages is highly influenced by temperature. The increase of temperature accelerated the developmental rate. During high temperature the duration of developmental stages are shortened and transformed to adult rapidly. It took only 4.22 days from egg to adult during the hot month (Table 1).

Table 1. Duration (day $\pm \mathrm{S} E$ ) of various developmental stages of $T$. urticae in different months reared on country bean leaf under laboratory condition.

\begin{tabular}{|c|c|c|c|c|c|}
\hline Months (Temp. ${ }^{\circ} \mathrm{C}$ ) & Egg to larva & Larva to protonymph & $\begin{array}{c}\text { Proto- to } \\
\text { deutonymph }\end{array}$ & $\begin{array}{l}\text { Deutonymph to } \\
\text { adult }\end{array}$ & Egg to adult \\
\hline Mar-02 (25.82) & $3.50 \mathrm{a} \pm 1.00$ & $2.00 \mathrm{a} \pm 0.72$ & $1.89 \mathrm{a} \pm 0.42$ & $2.24 \mathrm{a} \pm 0.44$ & $9.62 \mathrm{a} \pm 1.56$ \\
\hline Apr-02 (27.46) & $1.07 \mathrm{a} \pm 0.26$ & $1.21^{a} \pm 0.42$ & $\left.1.81^{\mathrm{a}} \pm 0.40\right)$ & $1.68^{a} \pm 0.48$ & $5.77 a \pm 0.75$ \\
\hline May-02 (28.53) & $1.62 \pm 0.49)$ & $0.55^{a} \pm 0.50$ & $0.89^{a} \pm 0.32$ & $1.15^{\mathrm{a}} \pm 0.37$ & $4.22^{a} \pm 0.46$ \\
\hline Jun-02 (29.60) & $1.60^{a} \pm 0.58$ & $1.00^{\mathrm{a}} \pm 0.00$ & $1.09 \mathrm{a} \pm 0.29$ & $1.18^{\mathrm{a}} \pm 0.40$ & $4.87 \mathrm{a} \pm 0.81$ \\
\hline Jul-02 (30.06) & $2.10^{\mathrm{a}} \pm 0.66$ & $\left.1.14^{a} 0.36\right)$ & $1.14^{\mathrm{a}} \pm 0.36$ & $1.68^{\mathrm{a}} \pm 0.56$ & $6.07 a \pm 0.80$ \\
\hline Aug-02 (29.41) & $2.66^{\mathrm{a}} \pm 0.67$ & $1.00^{a} \pm 0.00$ & $1.04 \mathrm{a} \pm 0.19$ & $0.92^{\mathrm{a}} \pm 0.41$ & $5.61 \mathrm{a} \pm 0.48$ \\
\hline Sep-02 (29.36) & $2.07^{\mathrm{a}} \pm 0.49$ & $0.93^{a} \pm 0.26$ & $1.00^{a} \pm 0.00$ & $1.44^{\mathrm{a}} \pm 0.51$ & $5.44 a \pm 0.75$ \\
\hline Oct-02 (27.07) & $2.62^{\mathrm{a}} \pm 0.70$ & $1.63^{\mathrm{a}} \pm 0.65$ & $1.79^{a} \pm 0.42$ & $2.09 \mathrm{a} \pm 0.43$ & $8.11 \mathrm{a} \pm 0.95)$ \\
\hline Nov-02 (23.32) & $4.89 \mathrm{a} \pm 0.81$ & $2.46^{b} \pm 0.51$ & $2.17^{\mathrm{a}} \pm 0.38$ & $2.70^{a} \pm 0.47$ & $12.21 \mathrm{a} \pm 1.23$ \\
\hline Dec-02 (18.59) & $11.40^{\mathrm{b}} \pm 2.01$ & $2.93^{b} \pm 1.07$ & $3.71 \mathrm{~b} \pm 1.94$ & $8.89^{b} \pm 2.08$ & $26.93^{b} \pm 2.45$ \\
\hline Jan-03 (13.78) & $11.67^{b} \pm 2.33$ & $2.69^{b} \pm 1.05$ & $3.71^{b} \pm 1.75$ & $10.26^{\mathrm{b}} \pm 1.48$ & $28.33^{b} \pm 2.36$ \\
\hline$F$ value & $355.66^{* * *}$ & $47.88^{\star \star \star}$ & $37.44^{\star \star *}$ & $319.51^{* \star *}$ & $875.39^{* \star *}$ \\
\hline LSD & 5.46 & 1.17 & 1.78 & 4.28 & 10.99 \\
\hline
\end{tabular}

Mean followed by same letter have no significant difference, ${ }^{* *}=\mathrm{P}>0.001$.

Table 2. Effect of temperature and relative humidity on the duration of different developmental stages of $T$. urticae.

\begin{tabular}{l|c|c|c}
\hline \multicolumn{1}{c|}{ Environmental factors } & \multicolumn{2}{c}{ Temperature } & Relative Humidity \\
\hline Developmental stage & 'r' value & Equation & 'r' value \\
\hline Egg & $-0.952^{* *}$ & $Y=-0.695 X+22.001$ & -0.126 \\
Larva & $-0.884^{* *}$ & $Y=-0.136 X+5.094$ & -0.395 \\
Protonymph & $-0.960^{* * *}$ & $Y=-0.187 X+6.675$ & -0.322 \\
Deutonymph & $-0.958^{* *}$ & $Y=-0.597 X+18.476$ & -0.134 \\
Adult & $-0.968^{* *}$ & $Y=-1.617 X+52.254$ & -0.181 \\
\hline
\end{tabular}


The developmental success of different developmental stages are calculated and presented in Table 3. The developmental success was not significantly different among months. At all conditions the developmental success of egg, larva and protonymph was more than $92 \%$. The developmental success of deutonymph was somewhat reduced in December and January when the average temperature was below $20^{\circ} \mathrm{C}$. The survivability from egg to adult was also abruptly reduced in December and January. The above findings shows that the cold temperature affect the survivability of late stages only.

Table 3. Developmental success of different stages of $T$. urticae as influenced by temperature and relative humidity.

\begin{tabular}{|c|c|c|c|c|c|c|c|}
\hline \multirow[b]{2}{*}{ Month } & \multicolumn{5}{|c|}{ Developmental success } & \multirow[b]{2}{*}{ Temp. $\left({ }^{\circ} \mathrm{C}\right)$} & \multirow{2}{*}{$\begin{array}{c}\text { Relative } \\
\text { Humidity (\%) }\end{array}$} \\
\hline & Egg & Larva & Proto-nymph & $\begin{array}{l}\text { Deuto- } \\
\text { nymph }\end{array}$ & $\begin{array}{l}\text { Egg to } \\
\text { adult }\end{array}$ & & \\
\hline March & 0.966 & 1.000 & 1.000 & 0.929 & 0.897 & 25.82 & 67.48 \\
\hline April & 1.000 & 1.000 & 0.929 & 0.962 & 0.893 & 27.46 & 76.75 \\
\hline May & 0.967 & 1.000 & 0.931 & 0.963 & 0.867 & 28.53 & 82.90 \\
\hline June & 0.926 & 0.960 & 0.917 & 1.000 & 0.815 & 29.60 & 85.49 \\
\hline July & 1.000 & 0.933 & 1.000 & 0.893 & 0.833 & 30.06 & 87.41 \\
\hline Aug & 1.000 & 0.966 & 0.964 & 0.889 & 0.828 & 29.41 & 85.82 \\
\hline Sept & 1.000 & 0.967 & 0.966 & 0.964 & 0.900 & 29.36 & 85.92 \\
\hline Oct & 0.929 & 0.923 & 0.958 & 0.957 & 0.786 & 27.07 & 82.31 \\
\hline Nov & 0.964 & 0.963 & 0.923 & 0.958 & 0.821 & 23.32 & 80.35 \\
\hline Dec & 1.000 & 0.967 & 0.966 & 0.643 & 0.600 & 18.59 & 81.83 \\
\hline Jan & 1.000 & 0.967 & 0.966 & 0.679 & 0.633 & 13.78 & 80.21 \\
\hline
\end{tabular}

$\mathrm{F}$ value $=0.95$

Fecundity of T. urticae: The mean number of eggs laid by a female, the daily fecundity and average duration of reproductive period during winter, autumn and summer is presented in Table 4. A female $T$. urticae laid $82.46 \pm 4.11$ eggs during autumn at average temperature of $25.23 \pm 2.65^{\circ} \mathrm{C}$ (Table 4 ) but it laid $58.21 \pm$ 13.65 eggs during winter with prevailing temperature $13.88 \pm 1.89^{\circ} \mathrm{C}$. The eggs deposited per day was only $1.35 \pm 0.36$ in winter but it was higher $(11.01 \pm 1.92)$ during summer when the average temperature was $30.46 \pm 2.61^{\circ} \mathrm{C}$.

Extensive research had been done on the biology of different species of spider mites. Most of the works are related to the effect of temperature. Sabelis (1981) reported that a female $T$. urticae develop from egg to adult in 6.5 days at $30^{\circ} \mathrm{C}$. Helle and Sabelis (1985) found that a female T. urticae lays as many as 60 eggs in five days. Shih (1999) observed T. urticae laid maximum 100 eggs in 10 days. He stated that the temperature $23-30^{\circ} \mathrm{C}$ was the optimal for the development of $T$. urticae. The larval and nymphal stage lasted 16 days at $20^{\circ} \mathrm{C}$ but only seven days at $31^{\circ} \mathrm{C}$. The present investigation shows that $T$. urticae develop from egg to adult in 4.22 and 28.33 days at temperature 28.53 and $13.78^{\circ} \mathrm{C}$ respectively. A female laid $62.96 \pm 12.09$ eggs during summer.

Table 4. Fecundity and reproductive period of $T$. urticae in winter, autumn and summer seasons.

\begin{tabular}{|c|c|c|c|}
\hline Season & Egg/female \pm SE & Egg/female/day \pm SE & Reproductive period day $\pm \mathrm{SE}$ \\
\hline Winter & $58.21 \pm 13.65$ & $1.35 \pm 0.36$ & $29.11 \pm 1.85$ \\
\hline Autumn & $82.46 \pm 4.12$ & $4.80 \pm 0.55$ & $18.75 \pm 1.07$ \\
\hline Summer & $62.96 \pm 12.09$ & $11.01 \pm 1.92$ & $9.28 \pm 1.17$ \\
\hline $\mathrm{F}$ value & $50.45^{\star \star *}$ & $12.95^{\star \star \star}$ & $1140.01^{* * *}$ \\
\hline
\end{tabular}


The effect of five constant temperatures $(15-370 \mathrm{C})$ at $80 \%$ relative humidity on the biology of $T$. neocaledonicus Andre in the laboratory was studied by Pande and Sharma (1986). They observed that $T$. neocaledonicus could not survive beyond $37^{\circ} \mathrm{C}$, but with the increase of temperature above $20^{\circ} \mathrm{C}$, development was faster. They also added that $30^{\circ} \mathrm{C}$ was the optimal temperature for the development of $T$. neocaledonicus. Northcraft and Watson (1987) studied the developmental biology of $T$. cinnabarinus at three fluctuating temperatures having the means $22.7,26.6$ and $30.5^{\circ} \mathrm{C}$. They reported that the developmental time, longevity and survival rate of adult females significantly decreased with the increase of temperature. Preoviposition periods and rate and duration of oviposition also tended to decrease with the increase of temperature. The mean generation time was $17.7,14.3$ and 11.6 days, respectively at $22.7,26.6$ and $30.5^{\circ} \mathrm{C}$. Deciyanto et al. (1989) studied the life cycle of Tetranychus sp. on six cultivars of Mentha piperita and $M$. arvensis. They found that the life cycle averaged within 10.6 to 14.4 days and a female laid 35.2 to 77 eggs. They also observed that the life cycle was the longest on $M$. piperita Newzealand but shortest on $M$. arvensis Jombang. Tsai et al. (1989) studied the duration of developmental stages of $T$. kanzawi infesting tea at $15,20,25$ and $30^{\circ} \mathrm{C}$. They found the lowest development at the lowest temperature and highest development at the highest temperature. The duration of the developmental stages were shorter at $30^{\circ} \mathrm{C}$ but longer at $15^{\circ} \mathrm{C}$. T. kanzawi was short lived at $30^{\circ} \mathrm{C}$ but long lived $15^{\circ} \mathrm{C}$. A female laid 27.8 eggs at $15^{\circ} \mathrm{C}$ but 76.0 eggs at $30^{\circ} \mathrm{C}$. The mean generation time ranged from 12.4 days at $30^{\circ} \mathrm{C}$ and 53.9 days at $15^{\circ} \mathrm{C}$. AlMallak and Abdalla (1990) studied the biology of strawberry mite, $T$. turkestani in laboratory condition at ${ }^{2} 5^{\circ} \mathrm{C}$ and $60 \% \mathrm{R}$. H. They reported the average egg laying capacity was $81.7 \pm 1.17$ per female. The larval, nymphal and adult stages lasted 6.2, 6.1 and 13.3 days respectively.

The result of present investigation agreed with the findings of the above results. All above results shows the great effect of temperature on the development and fecundity of $T$. urticae and other species of Tetranychus This experiment also found the significant effect of temperature on the developmental stages of $T$. urticae. The higher temperature accelerated the developmental rate and reduced the duration of developmental stages. In the present investigation the fecundity was also higher at $25.23 \pm 2.65^{\circ} \mathrm{C}$. At $30.46{ }^{\circ} \mathrm{C}$ the oviposition period was 9.28 days but it was 18.75 days at $25.23^{\circ} \mathrm{C}$. The life cycle of $T$. urticae completed within 4.22 days at $28.53^{\circ} \mathrm{C}$. So the present results suggest that favourable temperature of $T$. urticae was $25.23^{\circ} \mathrm{C}$ to $28.53^{\circ} \mathrm{C}$, which is very similar to the findings of other investigators on different species of spider mites.

\section{References}

Al-Mallak N N and S A Abdalla (1990) On the biology of strawberry mite, Tetranychus turkestani Ugarov and Nikoloski (Tetranychidae: Acariformes) and the susceptibility of three gladiolus cultivars to infestation under greenhouse condition. Arab J. Plant Prot. 8(1): 21-24.

Deciyanto S, M Amir M, Trisawa I and M Harijanto (1989) Study on biology and population development of Tetranychus sp. (Tetranychidae: Acarina) on Mentha spp. Pembaritaan Penilitian Taneman Industri (Indonesia) 15(10): 9-14.

Helle W and M W Sabelis (1985) Spider mites: Their biology, natural enemies and control. Volume 1 Part A. Elsevier, Amsterdam, $406 \mathrm{pp}$.

Johnson W T and H H Lyon (1991) Insects that feed on trees and shrubs. Comstock Publishing and Cornell University Press, Ithaca, NY.

Naher N (2005) Integrated pest management of two-spotted spider mite infesting beans. Unpublished Ph D Thesis, Rajshahi University, Bangladesh. 157 pp.

Northcraft P D and T E Watson (1987) Developmental biology of Tetranychus cinnabarinus (Boisduval) under three temperature regimes. Southwestern Entomologist 12(1): 45-50. 
Pande Y D and B L Sharma (1986) Effect of food and temperature on the biology of red cucurbit mite Tetranychus neocaledonicus Andre (Acarina: Tetranychidae). Revista Brasileira de Biologia 46(3): 597-602.

Sabelis M W (1981) Biological control of two-spotted spider mites using phytoseiid predators. Part 1. Modeling the predator-prey interaction at the individual level. Agricultural Research Reports No. 910. Wageningen, Netherlands.

Shih C I T (1999) Population ecology and its application on tetranychid and phytoseiid mite. Chinese J. Entomol. 126: $25-48$.

Tsai S M, K S Kung and C I T Shih (1989) The effect of temperature on life history and population parameters of kanzawa spider mite Tetranychus kanzawai Kishida (Acari: Tetranychidae) on tea. Plant Prot. Bull. Taiwan 31(2): 119-130.

Tuttle D M and E W Baker (1968) Spider mites of southern United States and a revision of the family Tetranychidae. Univ. Arizona Press. Tuscon, Arizona pp. 143. 